Original article

\section{Biogeographical factors determining Triatoma recurva distribution in Chihuahua, México, 2014}

María Elena Torres ${ }^{1}$, Hugo Luis Rojas ${ }^{1}$, Luis Carlos Alatorre ${ }^{1}$, Luis Carlos Bravo ${ }^{1}$, Mario Iván Uc ${ }^{1}$, Manuel Octavio González ${ }^{1}$, Lara Cecilia Wiebe ${ }^{1}$, Alfredo Granados²

${ }^{1}$ Unidad Multidisciplinaria, Universidad Autónoma de Ciudad Juárez, Cuauhtémoc, Chihuahua, México

${ }^{2}$ Instituto de Ingeniería y Tecnológica, Departamento de Ingeniería Civil y Ambiental, Juárez, Chihuahua, México

Introduction: Triatoma recurva is a Trypanosoma cruzi vector whose distribution and biological development are determined by factors that may influence the transmission of trypanosomiasis to humans.

Objective: To identify the potential spatial distribution of Triatoma recurve, as well as social factors determining its presence.

Materials and methods: We used the MaxEnt software to construct ecological niche models while bioclimatic variables (WorldClim) were derived from the monthly values of temperature and precipitation to generate biologically significant variables. The resulting cartography was interpreted as suitable areas for T. recurva presence.

Results: Our results showed that the precipitation during the driest month (Bio 14), the maximum temperature during the warmest month (Bio 5), and the altitude (Alt) and mean temperature during the driest quarter (Bio 9) determined T. recurva distribution area at a higher percentage evidencing its strong relationship with domestic and surrounding structures. Conclusions. This methodology can be used in other geographical contexts to locate potential sampling sites where these triatomines occur.

Keywords: Triatoma; Triatominae; ecosystem; Chagas' disease; disease vectors; climate.

Factores biogeográficos determinantes de la distribución de Triatoma recurva en Chihuahua, México, 2014

Introducción. Triatoma recurva es un vector de Trypanosoma cruzi cuya existencia y desarrollo biológico están determinados por factores que pueden influir en la transmisión de la tripanosomiasis a los seres humanos.

Objetivo. Determinar una posible distribución espacial de Triatoma recurva y algunos factores sociales que determinan su presencia.

Materiales y métodos. El modelado de nicho ecológico se hizo con el programa MaxEnt empleando las variables bioclimáticas (WorldClim) derivadas de los valores mensuales de temperatura y precipitación para generar variables biológicamente significativas. La cartografía resultante evidenció áreas adecuadas para la presencia de T. recurva.

Resultados. Los resultados indicaron que la precipitación del mes más seco (Bio 14), la temperatura máxima del mes más cálido (Bio 5), y la altitud (Alt) y la temperatura media del trimestre más seco (Bio 9), determinaron en mayor porcentaje el área de distribución de $T$. recurva, observándose que es una especie con una acentuada relación con las estructuras domésticas y circundantes.

Conclusión. Esta metodología puede emplearse en otros contextos geográficos para localizar posibles sitios de muestreo de estos triatominos.

Palabras clave: Triatoma; Triatominae; ecosistema; enfermedad de Chagas; vectores de enfermedades; clima.

Chagas disease or American trypanosomiasis is a parasitic blood and tissue disease caused by the flagellated protozoan Trypanosoma cruzi located in tissue, especially myocardial tissue. After a long evolutionary period $(1,2), T$. cruzi is known to cause irreversible heart disease in $25 \%$ of affected people. Its transmission cycle constitutes a complex zoonosis that involves several vertebrate reservoirs and insects among which Triatoma recurva is one of the chief ones. Trypanosoma cruzi can infect many tissues of mammalian hosts and spreads in the environment in multiple transmission cycles that may or may not be connected $(3,4)$. 
These insects belong to the order Hemiptera, infraorder Cimicomorpha, superfamily Reduvioidae, family Reduviidae, and subfamily Triatominae comprising more than 140 species grouped into 18 genera and five tribes. The habitats for their life cycles show considerable variability, and authors have indicated that some triatomine species can adapt to home environments and their peripheries where they transmit T. cruzi to humans (5).

Chagas disease is the most important parasitic disease in Latin America given its morbidity and economic importance. It surpasses all other parasitic diseases (6) and is the third most infectious disease in Latin America, second only to AIDS and tuberculosis. In Mexico, this type of zoonosis is associated with people's socio-economic level, which determines their access to resources, hygiene practices, and quality of housing, education, and sanitation, especially potable water and drainage systems $(7,8)$. Triatoma recurva represents a risk factor for the population at large $(9,10)$ but access to information about this type of zoonosis in nonendemic places is insufficient because the disease is not considered a risk and record-keeping of any related data is scant. Additionally, the gathering of epidemiological data regarding the death toll from Chagas disease is challenging (11) due to the lack of experience in its clinical diagnosis, which also affects decision making in medical surveillance limited at best.

Factors such as climate, rain, geographical barriers, humidity, topography, hosts, reservoirs, and causal agents determine T. recurva distribution and, therefore, its ability to transmit T. cruzi (12-14). The knowledge about the spatial location of these factors and the distribution of these Hemiptera can be extremely useful to detect populations vulnerable to diseases transmitted by these vectors.

Geographic Information Systems have become an epidemiological tool to monitor vector-transmitted diseases (15-17) and develop proper intervention strategies. To identify the biophysical variables required by a taxonomic group, Phillips, et al. developed a maximum entropy algorithm known as MaxEnt, which combines statistics and Bayesian methodology to estimate the distributions of the maximum entropy subject to environmental information constraints (18).

The geographical distribution of T. recurva is essential to study its natural, ecological, genetic, and evolutionary history, as well as to obtain the information needed to understand the different biogeographical and historical factors conditioning the different diseases it transmits. Such knowledge would contribute as well to foresee a potential emergence or reemergence of diseases transmitted by the vector and to extend the current view of the distribution of this important group of insects in México. In this context, the objective of our study was to identify the potential spatial distribution of $T$. recurva and the factors determining its presence.

\section{Materials and methods}

\section{Study area}

Chihuahua is in the central part of northern México (figure 1) bordering in the north the states of New Mexico and Texas in the United States, Coahuila de Zaragoza in the east, Durango state in the south, and Sinaloa state in the west. Its geographical coordinates are $25^{\circ} 30^{\prime}$ and $31^{\circ} 47^{\prime} \mathrm{N}$ and $103^{\circ} 18$ to $109^{\circ} 07 \mathrm{~W}$. It is México's largest state stretching across $12 \%$ of the nation's surface with a total area of $247.45 \mathrm{~km}^{2}$. Its climate is dry and semidry and the rainfall annual average is approximately $500 \mathrm{~mm}$ (19). 


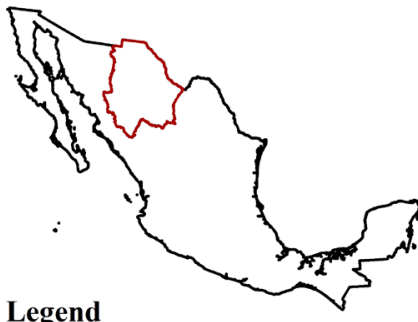

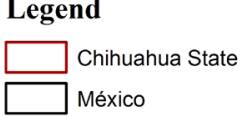

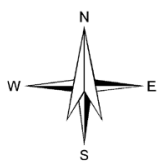

Legend

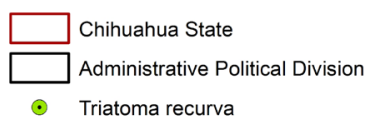

1 inch $=62.74$ miles

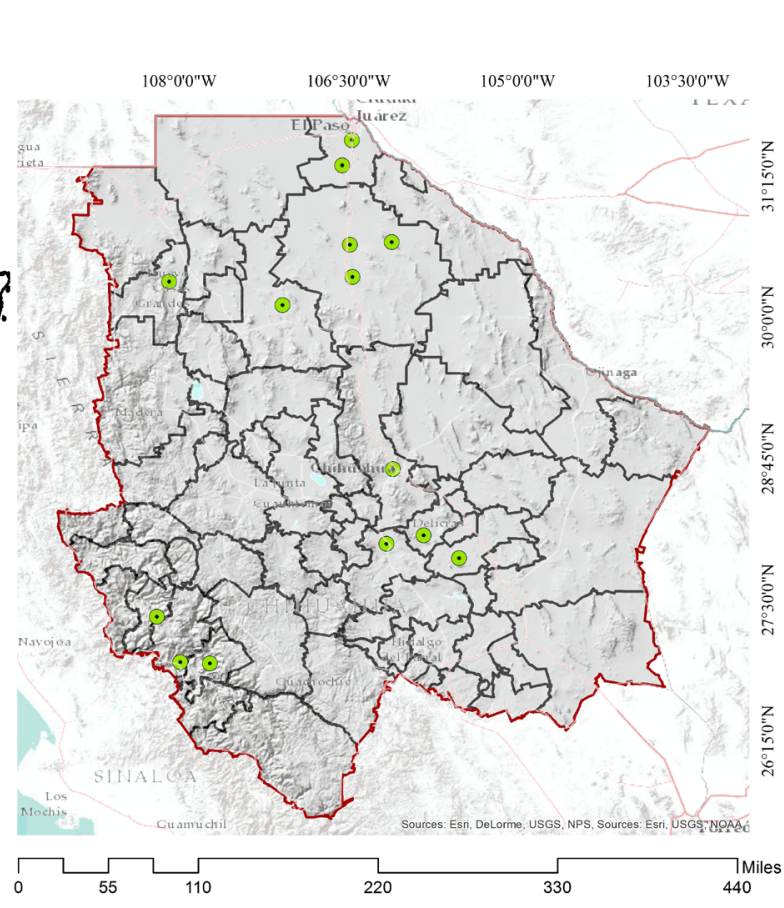

Origin: Elaboration based on layers of CONABIO (20) and several sources of the presence for Triatoma recurva

Figure 1. Area of study and presence of Triatoma recurva

\section{Database and procedures}

To generate the area of T. recurva potential distribution, we used 14 records of occurrence, all of them located in the state of Chihuahua. The points of presence were taken from the Global Biodiversity Information online website (1), Licón-Trillo (1), and the Centro Nacional de Programas Preventivos y Control de Enfermedades (Cenaprece) (12,20-23).

We used a group of biophysical variables: 19 climatological and five topographical derived from the digital elevation model (hillshade), accumulation of flux, slope, hillside facings, and altitude (Z) obtained from WorldClim (table 1). This database contains climate data corresponding to global climate layers with a homogenized resolution of $1 \mathrm{~km}$ obtained by cross-referencing weather station records (grids of $20 \times 20 \mathrm{~km}$, Environmental Systems Research Institute - ESRI format) from 1950 to 2000 from several sources at the global, national, regional, and local levels. These layers feature bioclimate variables derived from the monthly temperature and rainfall values to generate the most biologically significant variables representing annual tendencies and limiting factors for the species distribution (20).

We complemented this information with the vegetation tables of contents from the Normalized Difference Vegetation Index (NDVI) generated by the NASA MODIS sensor in 2014 (21-23). These tables have a temporary monthly resolution and a spatial resolution of $1 \mathrm{~km}^{2}$ (12 monthly NDVI variables by the 11th of each month) (MODIS. GSFC. NASA. gov/data-dataprod-mod13. php), as well as the land-use variable generated by the Instituto Nacional de Estadística y Geografía (INEGI) for land use and the V 2015 vegetation series available in the vectorial format at a 1:250,000 scale in the geosite of the Comisión Nacional para el Conocimiento y Uso de la Biodiversidad (CONABIO) with 37 variables in total (24). 


\section{Adjustment of the spatial resolution}

As the information collected was generated using different scales, it was necessary to standardize the scales based on the characteristics of the WorldClim variables ( $1 \mathrm{~km}$ given that MaxEnt does not work at different scales) (columns, rows, and pixel size) using ArcGis 10X with extraction using the mask module (25).

\section{Selection of variables}

The first step was to analyze the spatial correlation of the 37 predictor variables in the study area. For this, we calculated Spearman's correlation between pairs of variables that ruled out correlation values exceeding $R \geq 0.75$ because 0.5 to 0.7 coefficients tend to be relevant in small samples and this type of correlation avoids the oversizing of presence areas and should be used for data series with extreme values because Pearson's correlation calculations will affect the results $(26,27)$.

Additionally, we made a bootstrap resampling (1,000 repetitions) where the independent covariables were expected to be present in the largest number of bootstrap samples while noise variables were present as predictors in a lesser number of bootstrap samples (28). If it is carried out automatically, the advantage of this resampling technique is that it allows the estimation of an empirical distribution function through the resampling of the observed data and autocorrelation does not affect the selected model (table 1) (29).

The standard deviation was calculated with a confidentiality interval bias at $95 \%$ and a level of significance of $\alpha=0.025$ using the IBM SPSS Statistics ${ }^{\mathrm{TM}}$, version 20.0, software. This process yielded nine representative variables for the area of interest. Using the jackknife procedure we eliminated negative contributions and, thus, three variables were eliminated (Bio2, Somb, and Uso).

\section{Potential distribution}

First, it was necessary to debug the database with occurrence records. Each point records information on its location, i.e., latitude and longitude in decimal degrees. The preparation of the environmental variables comprised setting the type of format to ASCII because MaxEnt only recognizes this format and geospatially adjusting each variable to the study area.

We selected the MaxEnt algorithm because its application in previous works had yielded good results $(30,31)$ even with scant data (32), as in this case. Usually, in MaxEnt, the data are divided into two sets, one for the generation of the model and the other one for validation (33,34). However, as this procedure loses important information within the data set for validation (35), it is not suitable with small samples (35) but to solve the problem we resorted to a replication technique (bootstrapping) and generated 50 models. In this way, random partitions of data were made in each replication and each model was valued using a user-defined percent ( $50 \%$ in this case). In bootstrapping, sampling is performed by replacement indicating that the records of presence can be used more than one time in the validation dataset for each replication (36-38).

The biophysics variables were of the continuous type in our case. To estimate which variables were more relevant to the model, we discarded the variables that did not contribute to it using a jackknife test and then, the test was performed again with the newly debugged data (39). 
Table 1. Environmental parameters for species distribution models: WordClim (1950-2000), NDVI-MODIS 2014, topographic, and land-use variables

\begin{tabular}{ll}
\hline Variable & Description \\
\hline BIO1 & Annual mean temperature \\
BIO2 & Mean diurnal range** \\
BIO3 & Isothermality \\
BIO4 & Temperature seasonality \\
BIO5 & Maximum temperature of warmest month** \\
BIO6 & Minimum temperature of the coldest month \\
BIO7 & Temperature annual range ${ }^{\star *}$ \\
BIO8 & Mean temperature of the wettest quarter (3 months) \\
BIO9 & The mean temperature of the driest quarter (3 months) $)^{\star *}$ \\
BIO10 & Mean temperature of the warmest quarter (3 months) \\
BIO11 & Mean temperature of the coldest quarter (3 months) \\
BIO12 & Annual precipitation \\
BIO13 & Precipitation of wettest month \\
BIO14 & Precipitation of driest month ${ }^{\star *}$ \\
BIO15 & Precipitation seasonality \\
BIO16 & Precipitation of wettest quarter (3 months) \\
BIO17 & Precipitation of driest quarter (3 months) \\
BIO18 & Precipitation of warmest quarter (3 months) \\
BIO19 & Precipitation of coldest quarter (3 months) \\
NDVI1 & Normalized difference vegetation index to January, 2014 \\
NDVI2 & Normalized difference vegetation index to February, 2014 \\
NDVI3 & Normalized difference vegetation index to March, 2014 \\
NDVI4 & Normalized difference vegetation index to April, 2014 \\
NDVI5 & Normalized difference vegetation index to May, 2014 \\
NDVI6 & Normalized difference vegetation index to June, 2014 \\
NDVI7 & Normalized difference vegetation index to July, 2014 \\
NDVI8 & Normalized difference vegetation index to August, 2014 \\
NDVI9 & Normalized difference vegetation index to September, 2014 \\
NDVI10 & Normalized difference vegetation index to October, 2014 \\
NDVI11 & Normalized difference vegetation index to November, 2014 \\
NDVI12 & Normalized difference vegetation index to December, 2014 \\
Alt & Altitude Z ${ }^{\star *}$ \\
Acu & Accumulation of flux ${ }^{\star *}$ \\
Pend & Slope \\
Asp & Situation of hillsides \\
Somb & Hillshade** \\
Uso & Soil use** \\
\hline & \\
&
\end{tabular}

** Variables used for the model were obtained (not related among them) from Spearman's correlation $(<0.75, p=95 \%, a=0.025)$ and bootstrap of 1000 iterations.

The logistic output was chosen to obtain those values that were easier to understand and were processed later to be used as a probability value with values fluctuating between 0 and 1 where 0 showed incompatibility or absence of the species and 1, suitability, or likelihood of the species presence (40).

The evaluation process followed the parameters established by Phillips, et al. (31), using the characteristic receiver's operating curve $(R O C)$ to calculate the area under the curve (AUC), which was obtained by comparing the proportion of false and true positives, i.e., to show in two axes, $X$ and $Y$, the proportion of false positives (1-specificity) and on the Y-axis the proportion of true positives (sensitivity) (41). An AUC with a 0.5 value shows that the model has no predictive power, a value of 1 shows discrimination or a perfect model, and values below 0.5 show a much lesser relationship than that randomly expected $(42,43)$.

After generating the 50 models, we selected five maps from MaxEnt, specifically those with a greater area under the curve to incorporate them into the ESRI ArcGis, 10.2 version. Through map algebra, we calculated the average of such selection to obtain a consensus map and define the 
potentially sustainable areas for the species. Then we reclassified the values based on the threshold established by the MaxEnt: 10 percentile (a 10\% probability that the points of presence lied out of the prediction area of the whole potential distribution area) (44). Probabilities under the threshold were transformed into 0 and interpreted as the absence of hemipteran while those over the threshold were converted to 1 showing the presence of the species.

\section{Results}

The models, based on random subsets, were highly predictive of the distribution of T. recurva. The AUC results and highest percentages of the contribution of the two-variable model by replication showed sustained importance of the following variables (table 2): precipitation during the driest month, the maximum temperature of the warmest month, altitude (Alt), and mean temperature of the driest quarter, all indicating that the model ability to classify the presence was good and that it can be considered acceptable and more precise than that of a randomly obtained model.

The resulting cartography was obtained through the replicas $(6,16,17,26$, and 40) with an AUC more significant than 0.8 (figure 2). Table 2 shows the percentage contribution of the variables used to build the potential distribution model for T. recurve, the mean temperature of the driest quarter (Bio 9) being the most critical variable for its distribution (100\% contribution), followed by the highest temperature of the warmest month (Bio 5), the precipitation of the driest month (Bio 14) (99.4\%) and the altitude (Alt) (0.6\%).

However, the jackknife test indicated the variables bringing more information to the model when isolated: Bio 5 (maximum temperature of the warmest month), altitude (Alt), precipitation of the driest month (Bio 14), mean temperature of the driest quarter (Bio 9), and annual temperature range (Bio 7) (figure 3).

The resulting cartography can be interpreted as moderate to highly suitable areas in the municipalities of Buenaventura, Galeana, Ahumada Casas Grandes, Praxedis G. Guerrero, Batopilas, Urique, Morelos, Guachochi, Ascension, Ojinaga, Coyame del Sotol, Aldama, Manuel Benavides, Julimes, Delicias, Rosales, Saucillo, Meoqui, La Cruz, Allende Hidalgo del Parral, Matamoros, and Coronado.

Table 2. Area under the curve and highest percentage contribution of variables by reply

\begin{tabular}{lllc}
\hline $\begin{array}{l}\text { Number } \\
\text { of models }\end{array}$ & AUC & Variable of importance & $\begin{array}{c}\text { Percentage } \\
\text { contribution }\end{array}$ \\
\hline 17 & 0.8526 & Precipitation of driest month & 72.1 \\
& & Max temperature of warmest month & 27.9 \\
16 & 0.8449 & Max temperature of warmest month & 89.6 \\
& & Precipitation of driest month & 10.4 \\
26 & 0.8243 & Max temperature of warmest month & 58.5 \\
& & Precipitation of driest month & 41.5 \\
40 & 0.8145 & Precipitation of driest month & 99.4 \\
& & Altitude & 0.6 \\
6 & 0.8136 & Mean temperature of driest quarter & 100 \\
\hline \multirow{2}{*}{ AUC: area under the curve }
\end{tabular}




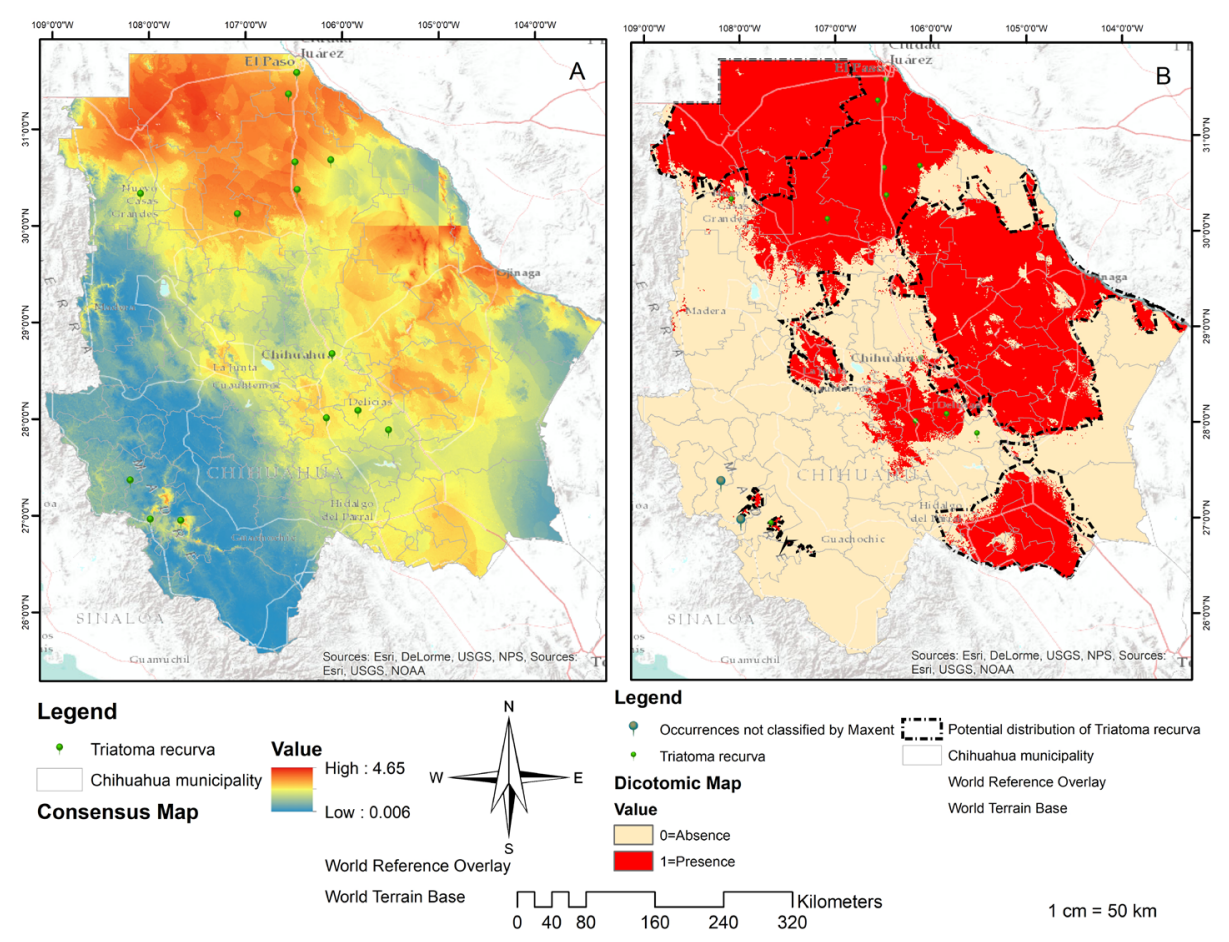

Figure 2. Distribution of Triatoma recurva. Consensus map (A): Result of the addition of the five models with $A U C<0.8$. Source: Individual elaboration based on the results obtained by the modeling in MaxEnt and algebra of maps. Map of presence/absence (B) for the Triatoma recurva generated by the reclassification and algebra of maps. Source: Individual elaboration based on the results of MaxEnt, the reclassification by the percentile 10, and algebra of maps. The dotted line shows favorable environmental conditions for the presence of Triatoma recurve in Chihuahua state (potential distribution). There are also two occurrences not classified by Maxent.

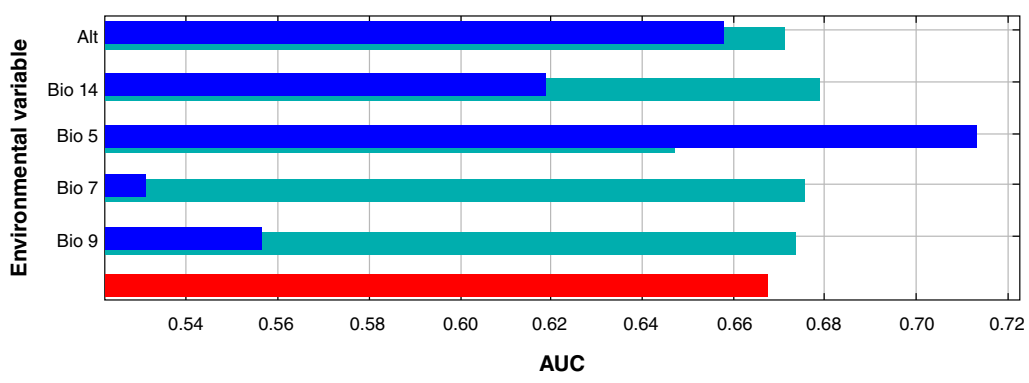

Without variable With only variable With all variable

Figure 3. Jackknife test of the area under the curve (AUC) for Triatoma recurva. Profit generated by each variable in three different scenarios: (a) running the model with only one variable (blue); (b) with all the variables except one (green), and (c) with all the variables (red). This reflects how much useful information each variable contains.

\section{Discussion}

The biogeographical approximation we adopted in the present study was based on the potential distribution of T. recurva, which is the only component involved in the vectorial transmission dynamics of Chagas disease, a zoonosis that must be understood as an extremely complex natural system.

The values of the area under the curve (greater than 0.8 ) in the T. recurva models were above the random prediction parameter $(A U C=0.50)$ indicating that the model's ability to classify the presence of the species is acceptable and more precise than a randomly obtained model. 
Additionally, this result is consistent with reports from other authors (4549). MaxEnt was proven to be a useful tool for modeling using only the data of presence, making predictions with low numbers of presence, and improving the performance of numerous traditional techniques.

Regarding the AUC jackknife test, we noticed that Bio 5 (highest temperature of the warmest month) is the highest-contributing variable to the isolated model form, followed by the mean temperature of the driest quarter (Bio 9), the altitude (Alt), the precipitation of the driest month (Bio 14), and the annual temperature range (Bio 7). These five variables bear a relationship to each other and explain why several authors consider them as constraining factors for this species (50-54).

The cartography resulting from the MaxEnt model can be interpreted as the potential areas in the above-mentioned municipalities and they explain why $T$. recurva has a higher probability of existing in those places due to their environmental conditions. However, triatomine bugs could be present in all the northern cone of Chihuahua (figure $2 A)(55,56)$. The map of the absence or presence defines the potential distribution of T. recurva (figure $2 \mathrm{~B}$ ) but its biological and geographical information is limited because this species is rarely collected and its breeding in the laboratory is challenging (57).

Two omissions (figure 2B) can be attributed to the generated model, which will not be accurate given that the occurrences were non-representative, to a misidentification of species, georeferencing, or to the fact that the presence of the species include individuals outside their native distribution (58). However, some authors have indicated that in some models small areas contain the corresponding species showing that they are not absent but that their distribution has lost continuity in these areas and generated isolated populations due to the historical or recent fragmentation of their habitat.

The data previously mentioned show T. recurva's capacity of adjustment to different environments. In the present study, we identified possible patterns of the distribution of medically important Hemiptera. Among the 37 variable predictors used in the modeling, four predicted the potential distribution of T. recurva (mean temperature of the driest quarter, Bio 9; the maximum temperature of the warmest month, Bio 5; precipitation of the driest month, Bio 14, and altitude, Alt) (45,50-53). The cartography of the potential spatial distribution of T. recurva was generated through modeling using maximum entropy.

Given the resurgence of diseases transmitted by Hemiptera, these results can be helpful to generate a hypothesis and identify critical locations where diseases caused by this vector spread and are transmitted. The AUC values reached indicated that the model predicts the distribution of triatomine bugs in Chihuahua, México, with a very acceptable degree of precision, higher than those obtained randomly, thus confirming our findings and the validity of the model obtained.

More attention should be given to the variables that intervene importantly in the generation of this model because they indicate the presence of Hemiptera and allow for the development of control and sanitation strategies to avoid epidemics in the country. The knowledge on the biogeographical process of vectors such as Hemiptera is essential for the development, planning, and optimization of preventive actions and vector control. The modeling of the potential occurrence of $T$. recurva is an approach to identify the vulnerable zones in the country and they should be considered valid tools. 
More in-depth studies are required to develop government programs for the control of vector-borne diseases.

The present study contributes basic information to feed the nation's epidemiological surveillance system focusing on those states where the suitability map has the highest values or where sub-records indicate the presence of these vectors. This methodology can be used in other geographical contexts to locate potential sampling sites where these triatomines occur.

\section{References}

1. Vidal-Acosta V, Ibáñez-Bernal S, Martínez-Campos C. Infección natural de chinches Triatominae con Trypanosoma cruzi asociadas a la vivienda humana en México. Salud Pública de México. 2000;42:496-503.

2. Castro T, Hernández-Betancourt S, Puerto FI, Torres-León M. Lesiones histológicas asociadas a la posible infección por Trypanosoma cruzi (Chagas, 1909) en corazones de roedores sinantrópicos capturados en Yucatán, México. An Biol. 2016;38:29-35. https://doi.org/10.6018/analesbio.38.03

3. Medone P. Biogeografía de los insectos vectores de la enfermedad de Chagas: influencia de las variables ambientales sobre la distribución de los triatominos en América (tesis). Accessed: October 6, 2018. Available at: http://sedici.unlp.edu.ar/handle/10915/52775

4. Rivas N, Sánchez-Espíndola E, Camacho AD, Alejandre-Aguilar R. Comparative egg morphology of six Meccus species and Triatoma recurva (Stål, 1868) Hemiptera: Reduviidae. J Vector Ecol. 2016;41:135-41. https://doi.org/10.1111/jvec.12205

5. Padilla-Narváez FA. Ciclo de vida, hábitos de alimentación y defecación de Triatoma carrioni (Larrouse, 1926) pertenecientes a la provincia de Loja, bajo condiciones controladas de laboratorio. Accessed: October 6, 2018. Available at: http://repositorio.puce.edu.ec/handle/22000/10386

6. World Health Organization. The world health report 2002: Reducing risks, promoting healthy life. Accessed: October 6, 2018. Available at: https://www.who.int/whr/2002/en/

7. Nash D, Mostashari F, Fine A, Miller J, O'leary D, Murray K, et al. The outbreak of West Nile virus infection in the New York City area in 1999. New Engl J Med. 2001;344:1807-14. https://doi.org/10.1056/NEJM200106143442401

8. Ramírez-Sierra MJ, Dumonteil E. Infection rate by Trypanosoma cruzi and biased vertebrate host selection in the Triatoma dimidiata (Hemiptera: Reduvidae) species complex. J Med Entomol. 2016;53:20-5. https://doi.org/10.1093/jme/tjv168

9. Montenegro D, Vera M, Zuleta L, Llanos V, Junqueira A. Estrategia para determinar la línea base en áreas de interrupción vectorial de la enfermedad de Chagas. Rev Panam Salud Pública. 2016;39:341-51

10. Monroy ÁL, Pedraza AM, Prada CF. Prevalence of anti-Trypanosoma cruzi antibodies in women of childbearing age in Socotá, Boyacá, 2014. Biomédica. 2016;36:90-6. https://.doi.org/10.7705/biomedica.v36i3.2923

11. Ramsey J, Ordóñez R, Tello-López A, Pohls J, Sánchez V, Peterson A. Actualidades sobre la epidemiología de la enfermedad de Chagas en México. México: Instituto Nacional de Salud Pública; 2003. p. 85-104.

12. Parra-Henao G, Quirós-Gómez O, Jaramillo-O N, Cardona Ás. Environmental determinants of the distribution of Chagas disease vector Triatoma dimidiata in Colombia. Am J Trop Med Hyg. 2016;94:767-74. https://doi.org/10.4269/ajtmh.15-0197

13. Cajo DJ, Moreno M, Chaguamate L, Valencia N, Ayala VR. Aplicación de modelos de nicho ecológico para estudios epidemiológicos: Triatoma dimidiata, vector de la enfermedad de Chagas en Ecuador. Revista Politécnica. 2016;37:88:92.

14. Marín E, Exébio C, Santillán R, Cuba C, Jurberg J, Galvão C. Observaciones de campo y algunos parámetros biológicos de los triatominae (Hemiptera: Reduviidae), vectores de la enfermedad de Chagas en el noriente de Perú. Pueblo Continente. 2014;25:53-74.

15. Morris $\mathrm{E}$, Bone $\mathrm{C}$. Identifying spatial data availability and spatial data needs for Chagas disease mitigation in South America. Spat Spatiotemporal Epidemiol. 2016;17:45-58. https://doi.org/10.1016/j.sste.2016.04.006 
16. Gentry J, Sturm B, Peterson AT. Predictive mapping of transmission risk of a soil-transmitted helminth across East Africa: Findings from community prevalence surveys. J Public Health Dev Ctries. 2016;2:150-61.

17. Quinde-Calderón L, Ríos-Quituizaca P, Solorzano L, Dumonteil E. Ten years (2004-2014) of Chagas disease surveillance and vector control in Ecuador: Successes and challenges. Trop Med Int Health. 2016;21:84-92. https://doi.org/10.1111/tmi.12620

18. Urbina-Cardona JN, Loyola RD. Applying niche-based models to predict endangered-Hylid potential distributions: Are neotropical protected areas effective enough? Trop Conserv Sci. 2008;1:417-45. https://doi.org/10.1177/194008290800100408

19. INEGI. Territorio, población y economía de México, 2010. Accessed: August 25, 2018. Available at: http://www3.inegi.org.mx/sistemas/spc/Default.aspx

20. Hijmans RJ, Cameron SE, Parra JL, Jones PG, Jarvis A. Very high resolution interpolated climate surfaces for global land areas. Int J Climatol. 2005;25:1965-78. https://doi.org/10.1002/joc.1276

21. Young N, Carter L, Evangelista P. A MaxEnt model v3. 3.3 e tutorial (ArcGIS v10). Accessed: August 20, 2018. Available at: https://www.coloradoview.org/wp-content/coloradoviewData/ trainingData/a-maxent-model-v8.pdf

22. Kawashima RS, Siqueira MF, Mantovani JE. Dados do monitoramento da cobertura vegeta por NDVI na modelagem da distribuição geográfica potencial do lobo-guará (Chrysocyon bracyurus). Florianópolis, Brasil: INPE; 2017. p. 3983-90.

23. Cruz-Cárdenas G, Villaseñor JL, López-Mata L, Martínez-Meyer E, Ortiz E. Selección de predictores ambientales para el modelado de la distribución de especies en Maxent. Rev Chapingo Ser Cie. 2014;20:187-201. https://doi.org/10.5154/r.rchscfa.2013.09.034

24. García E. Modificaciones al sistema de clasificación climática de Köppen. 5th edition. México D.F.: Instituto de Geografía UNAM; 2004.

25. González Lozano FA. Manual introductorio ArcGis 10.2. Accessed: August 20, 2018. Available at: http://bdigital.unal.edu.co/50837/1/manualintroductorioArcGis10.2.pdf

26. Torres R, Jayat JP. Modelos predictivos de distribución para cuatro especies de mamíferos (Cingulata, Artiodactyla y Rodentia) típicas del Chaco en Argentina. Mastozool Neotrop. 2010;17:335-52.

27. Martínez-Ortega RM, Tuya-Pendás LC, Martínez-Ortega M, Pérez-Abreu A, Cánovas AM. El coeficiente de correlación de los rangos de Spearman, caracterización. Revista Habanera de Ciencias Médicas. 2009;8:5.

28. Austin PC, Tu JV. Bootstrap methods for developing predictive models. Am Stat. 2004;58:131 7. https://doi.org/10.1198/0003130043277

29. Quiñones UM, Valerio PD, Ramos JH, Sánchez AM, Magaña JJ, Granados MC. Similaridad del nicho ecológico de Pinus montezumae y P. pseudostrobus (Pinaceae) en México: implicaciones para la selección de áreas productoras de semillas y de conservación. Acta Bot Mex. 2019. https://doi.org/10.21829/abm126.2019.1398

30. Elith J, Graham $\mathrm{CH}$, Anderson RP, Dudík M, Ferrier S, Guisan A, et al. Novel methods improve prediction of species' distributions from occurrence data. Ecography. 2006;29:12951. https://doi.org/10.1111/j.2006.0906-7590.04596.x

31. Phillips SJ, Anderson RP, Schapire RE. Maximum entropy modeling of species geographic distributions. Ecol Model. 2006;190:231-59. https://doi.org/10.1016/j.ecolmodel.2005.03.026

32. Riverón-Giró FB, Raventós J, Damon A, García-González A, Mújica E. Spatio-temporal dynamics of the invasive orchid Oeceoclades maculata (Orchidaceae), in four different habitats in southeast Chiapas, Mexico. Biol Invasions. 2019;21:1905-19. https://doi.org/10.1007/s10530-019-01945-7

33. Duque PL, Liria J, Burgaleta E, Salazar J, Arrivillaga-Henríquez J, Enríquez S, et al. High mosquito diversity in an Amazonian village of Ecuador, surrounded by a Biological Reserve, using a rapid assessment method. J Entomol Acarological Res. 2019;51. https://doi.org/10.4081/jear.2019.7775

34. Pearson RG, Raxworthy CJ, Nakamura M, Townsend-Peterson A. Predicting species distributions from small numbers of occurrence records: a test case using cryptic geckos in Madagascar. J Biogeogr. 2007;34:102-17. https://doi.org/10.1111/j.1365-2699.2006.01594.x

35. Liu C, Newell G, White M. The effect of sample size on the accuracy of species distribution models: Considering both presences and pseudo-absences or background sites. Ecography. 2019;42:535-48. https://doi.org/10.1111/ecog.03188 
36. Lyon NJ, Debinski DM, Rangwala I. Evaluating the utility of species distribution models in informing climate change-resilient grassland restoration strategy. Fron Ecol Evol. 2019;7:33. https://doi.org/10.3389/fevo.2019.00033

37. Fletcher Jr RJ, Hefley TJ, Robertson EP, Zuckerberg B, McCleery RA, Dorazio RM. A practical guide for combining data to model species distributions. Ecology. 2019;100. https://doi.org/10.1002/ecy.2710

38. Støa B, Halvorsen R, Stokland JN, Gusarov VI. How much is enough? Influence of number of presence observations on the performance of species distribution models. Sommerfeltia. 2019;39:1-28. https://doi.org/10.2478/som-2019-0001

39. Abdelaal M, Fois M, Fenu G, Bacchetta G. Using MaxEnt modeling to predict the potential distribution of the endemic plant Rosa arabica Crép. in Egypt. Ecol Inform. 2019;50:68-75. https://doi.org/10.1016/j.ecoinf.2019.01.003

40. Kariminejad N, Hosseinalizadeh M, Pourghasemi HR, Bernatek-Jakiel A, Campetella $\mathrm{G}$, Ownegh M. Evaluation of factors affecting gully headcut location using summary statistics and the maximum entropy model: Golestan Province, NE Iran. Sci Total Environ. 2019;677:281-98. https://doi.org/10.1016/j.scitotenv.2019.04.306

41. Chen X, Dimitrov NB, Meyers LA. Uncertainty analysis of species distribution models. PLOS ONE. 2019;14:1-11. https://doi.org/10.1371/journal.pone.0214190

42. Fielding $\mathrm{AH}$, Bell JF. A review of methods for the assessment of prediction errors in conservation presence/absence models. Environ Conserv. 1997;24:38-49. https://doi.org/10.1017/S0376892997000088

43. Guisan A, Broennimann O, Engler R, Vust M, Yoccoz NG, Lehmann A, et al. Using nichebased models to improve the sampling of rare species. Conserv Biol. 2006;20:501-11. https://doi.org/10.1111/j.1523-1739.2006.00354.x

44. Naranjo M, Moreno ÁC, Martín S. ¿Dónde buscar troglobiontes? Ensayo de una cartografía predictiva con MaxEnt en Gran Canaria (islas Canarias). Arxius de Miscellània Zoològica. 2014;12:83-92. https://doi.org/10.32800/amz.2014.12.0083

45. Comisión Nacional para la Biodiversidad. Portal de geoinformación, Sistema Nacional de Información Sobre Biodiversidad. Accessed: August 12, 2018. Available at: http://www.conabio.gob.mx/informacion/gis/

46. Waleckx E, Cámara-Mejía J, Ramírez-Sierra MJ, Cruz-Chan V, Rosado-Vallado M, VázquezNarváez S, et al. Una intervención innovadora de ecosalud para el control vectorial de la enfermedad de Chagas en Yucatán, México. Revista Biomédica. 2015;26:75-86.

47. Peña J, Perdomo LM, Cuartas DE. Geografía de la Salud, una visión de pasado y presente. Entorno Geográfico. 2013;9:146-58.

48. Chaves M, Esteban C, Gómez-Mantilla MA, Ballesteros-Orduz MF, Rangel-Laguado MA, Concha-Sánchez JG. Manual de modelamiento de datos geoespaciales para la identificación de la vocación agrológica de los predios del municipio de Piedecuesta según el dato del IGAC para el cultivo de la mora. Accessed: August 12, 2018. Available at: http://repositorio.uts.edu.co:8080/xmlui/handle/123456789/7821

49. Lorenzo MG, Guarneri AA, Pires HH, Diotaiuti L, Lazzari CR. Microclimatic properties of the Triatoma brasiliensis habitat. Cad Saúde Pública. 2000;16:S69-S74. https://doi.org/10.1590/S0102-311X2000000800007

50. Carbajal-de la Fuente AL, Fernández MP, Piccinali RV, Rodríguez-Planes LI, Duarte R, Gürtler RE. Occurrence of domestic and intrusive triatomines (Hemiptera: Reduviidae) in sylvatic habitats of the temperate Monte Desert ecoregion of Argentina. Acta trop. 2019;196:37-41. https://doi.org/10.1016/j.actatropica.2019.04.028

51. Guarneri A, Diotaiuti L, Lazzari C, Lorenzo MG. The effect of relative humidity on Triatoma brasiliensis: Hygropreference and eclosion success. Mem Inst Oswaldo Cruz. 1998;93:349.

52. Parra-Henao G, Suárez-Escudero LC, González-Caro S. Potential distribution of Chagas disease vectors (Hemiptera: Reduviidae: Triatominae) in Colombia, based on ecological niche modeling. J Trop Med. 2016;2016:1-10. https://doi.org/10.1155/2016/1439090

53. Obara MT, da Silva Cardoso A, Pinto MC, de Souza CR, Silva RA, Gurgel-Gonçalves R. Eratyrus mucronatus Stål, 1859 (Hemiptera: Reduviidae: Triatominae): first report in the State of Acre, Brazil, and updated geographic distribution in South America. Check List. 2013;9:851-4. https://doi.org/10.15560/9.4.851 
54. Di Luciano VS. Orientation of Triatoma infestans (Hemiptera: Reduviidae) to environmental temperatures. J Med Entomol. 1983;20:446-54.

55. Balsalobre A. ¿Qué especies de vinchucas modificarán su distribución geográfica en la Argentina? Accessed: August 21, 2018. Available at: http://sedici.unlp.edu.ar/ handle/10915/52319

56. Martínez-Ibarra JA, Paredes-González E, Montañez-Valdez OD, Rocha-Chávez G, Nogueda-Torres B. La biología de tres especies mexicoamericanas de Triatominae (Hemiptera: Reduviidae): Triatoma recurva, Triatoma protracta y Triatoma rubida. Mem Inst Oswaldo Cruz. 2012;107:659-63. https://doi.org/10.1590/S0074-02762012000500013

57. Anderson RP, Lew D, Peterson AT. Evaluating predictive models of species' distributions: Criteria for selecting optimal models. 2003; Ecological Modelling 162:211-32. https://doi.org/10.1016/S0304-3800(02)00349-6

58. Paredes-García DM, Ramírez-Bautista A, Martínez-Morales MA. Distribución y representatividad de las especies del género Crotalus en las áreas naturales protegidas de México. Revista Mexicana de Biodiversidad. 2011;82:689-700. 